\title{
Statistical Analysis of Habbatussauda's Benefits for Health (Blood Pressure, Glucose and Uric Acid)
}

\author{
Sugiyanto $^{1}$,*, Luqyana Khalda' Aesa ${ }^{2}$, Meksianis Z. Ndii ${ }^{3}$ \\ ${ }^{1,2}$ Departement of Mathematics, Universitas Islam Negeri Sunan Kalijaga, Yogyakarta, Indonesia. \\ ${ }^{3}$ Department of Mathematics, Faculty of Science and Engineering, University of Nusa Cendana, Kupang-NTT, Indonesia. \\ Author correspondency*: \\ sugimath@yahoo.co.id
}

\begin{abstract}
Habbatussauda is one of the traditional medicine existed since a long time ago and this is one of the drugs that recommended by the Prophet Muhammad. Habbatussauda's benefits have been studied extensively in the healthcare. Habbatussauda has also been widely used to cure various diseases. This study revealed the benefits of Habbatussauda in lowering blood pressure, glucose and uric acid levels in 20 respondents that given Habbatussauda for 2 weeks. The blood pressure, glucose and uric acid levels were measured before and after consuming Habbatussauda. Blood pressure, glucose, and uric acid levels in the body will decrease after consuming Habbatussauda that shown in the statistical analysis of the obtained data.
\end{abstract}

Keywords: Blood pressure; Glucose; Habbatussauda; Herbal medicine; Statistical analysis; Uric acid

\section{INTRODUCTION}

Based on data from WHO (World Health Organization) in 2010, the population of Indonesia is 249.866.000, makes Indonesia to be one of the most populated countries. Increasing number of population will certainly make many problems, one of them is a health problem. Some health problems that frequently occur in Indonesia are increased glucose level, increased blood pressure, obesity, and many more, whereas the highest rate of disease caused death are: stroke, coronary heart disease, diabetes mellitus, respiratory infections, tuberculosis, liver cirrhosis, lung disease, and hypertension.

It makes a lot of Indonesians searching for alternative medicines or just preventive medicines of various diseases. One of them is the herbal treatments, which is currently in great demand, one of them is Nigella sativa, or commonly known as black cumin, black seed or Habbatussauda.

Habatussauda is one of the traditional medicines used by people to cure various diseases. Prophet Muhammad said that Habatussauda can cure all diseases except death (Osman et al., 2014). Contemporary naturopathic medicine all over the world have been using Habbatussauda which has Thymoquinone as a major component (Salahshoor et al., 2018). Thymoquinone contained in the Habbatussauda has a protection function to counter nephrotoxicity and hepatotoxicity. It also has pharmacological effects which include antihelmintic, anticestoda, and antischistosoma, antibacterials, antifungi, antiviral, antioxidant, antiinflammatory, and can improve the immune response of cells that are mediated T (Abdulelah \& Abidin, 2007).
Habbatussauda can be used for antihypertensive treatment, antitumor, antibacterial, antioxidant, antidiabetic and antidyslipidemia (Hussain \& Hussain, 2016). Other benefit of Habbatussauda is antihyperuricemia (Suhendi \& Sutrisna, 2011). Habbatussauda is also used as a diuretic (Aboul-Enein \& Abou-Basha, 1995). The study of Habbatussauda's benefits are quite a lot and still being developed. Mathematics has an important role in knowing the benefits of Habbatussauda, by using statistics. Statistics used to process the primary data the obtained Habbatussauda's benefit data will be processed by statistic methods.

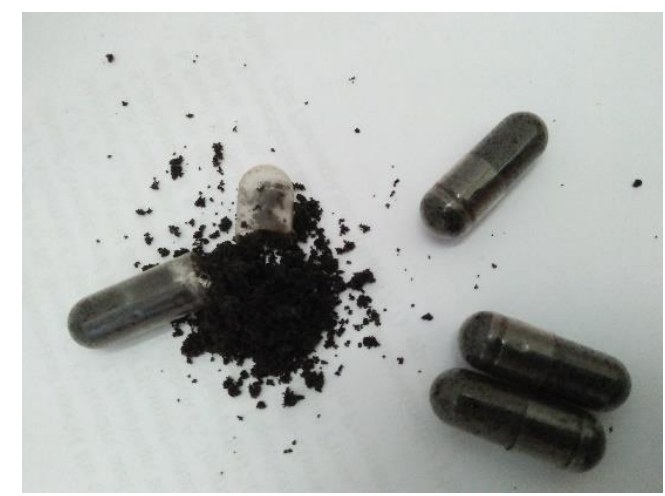

Figure 1. Habbatussauda Powder.

\section{MATERIALS AND METHODS}

In this study, respondents from ages between $19-23$ years old with the sample size of 20 respondents (11 
female, 9 male). Taken respondents do not have history of serious illness, disease history owned by the respondents include stomach ucler, typhoid, and dengue fever. In this study, respondents did not consume other medicine besides Habbatussauda that given by the researchers. Respondents were students of UIN Sunan Kalijaga who had a history of stomach ucler, typhoid, and dengue fever.

Before starting the study, first thing to to check is a blood test to determine the initial value of blood pressure, glucose and uric acid before giving each respondent the Habbatussauda. Furthermore, respondents who take a blood test will be given 42 Habbatussauda capsule for two weeks consumption, the respondent consumes 3 Habbatussauda capsules daily, each capsule contains $600 \mathrm{mg}$ of pure Habbatussauda. Habbatussauda used is the type of powder brand Kurma Ajwa containing 120 Capsules. Then the blood test were carry on after two weeks to take final value of respondent's blood pressure, glucose and uric acid after consuming Habbatussauda to know whether it decrease or increase.

During the two weeks Habbatussauda consumption, respondents were contacted by phone to remind them to consume Habbatussauda and ask them if there are any complaints or perceived side effects while taking the Habbatussauda. Taking blood samples to check the measure of glucose and uric acid is done by taking a blood sample from the respondent, then checked it by using the glucose and uric acid tool check, whereas for checking blood pressure was checked by using sphygmomanometer.

The data before and after consumption of Habbatussauda taken from respondents were collected, then statistical analysis was perform using several kinds of tests, using Statistical Package for Social Science (SPSS) version 15.0. The first test used to test for normality of $95 \%$ significance level to determine whether the obtained data is normally distributed or not. Then after the normality test, $\mathrm{t}$ test was perform with $95 \%$ significance level to determine whether there is a significant difference in the average before and after consumption of Habbatussauda. At this $\mathrm{t}$ test if the value of sig is more than 0.05 then the two data do not have significant differences, but if sig is less than 0.05 then the data is a significant difference.

\section{RESULTS}

The average research results that have been obtained from 20 respondents are as follows (Table 1).

According Table 1. average of the systole before consuming Habbatussauda is $119.1 \mathrm{mmHg}$ and average of the diastole before consuming Habbatussauda is a $81.6 \mathrm{mmHg}$. While the average of the systole after consuming Habbatussauda is $111.35 \mathrm{mmHg}$ and average diastole after consuming Habbatussauda is 75.9 mmHg.

Table 1. Blood pressure average before and after consuming Habbatussauda.

\begin{tabular}{lcc}
\hline \multirow{2}{*}{ Average } & \multicolumn{2}{c}{ Blood Pressure } \\
\cline { 2 - 3 } & $\begin{array}{c}\text { Systole } \\
\text { (mmHg) }\end{array}$ & $\begin{array}{c}\text { Diastole } \\
\text { (mmHg) }\end{array}$ \\
\hline Before consuming Habbatussauda & 119.1 & 81.6 \\
After consuming Habbatussauda & 111.35 & 75.9 \\
\hline
\end{tabular}

Table 2. Glucose average before and after consuming Habbatussauda.

\begin{tabular}{lc}
\hline Average & Glucose (mg/dL) \\
\hline Before consuming Habbatussauda & 90.3 \\
After consuming Habbatussauda & 84.6 \\
\hline
\end{tabular}

According Table 2, average of the glucose level before consuming Habbatussauda is a $90.3 \mathrm{mg} / \mathrm{dL}$, while the average of the glucose after consuming Habbatussauda is a $84.6 \mathrm{mg} / \mathrm{dL}$.

Table 3. Uric acid average before and after consuming Habbatussauda.

\begin{tabular}{cc}
\hline \multicolumn{1}{c}{ Average } & $\begin{array}{c}\text { Uric Acid } \\
\text { (mg/dL) }\end{array}$ \\
\hline Before consuming Habbatussauda & 5.065 \\
After consuming Habbatussauda & 4.555 \\
\hline
\end{tabular}

According Table 3, average of the uric acid before consuming Habbatussauda is a 5.065, while the average of the uric acid after consuming Habbatussauda is 4.555 $\mathrm{mg} / \mathrm{dL}$.

Furthermore, the test for normality using the Shapiro-Wilk test described below in the following table.

Table 4. Test result Shapiro-Wilk Blood Pressure.

\begin{tabular}{|c|c|c|c|}
\hline \multicolumn{4}{|c|}{ Shapiro-wilk } \\
\hline & $\begin{array}{l}\text { Statistic } \\
(\mathrm{mmHg})\end{array}$ & Df & $\boldsymbol{P}$ \\
\hline $\begin{array}{l}\text { Systole before consuming } \\
\text { Habbatussauda }\end{array}$ & 0.9191 & 20 & 0.096 \\
\hline $\begin{array}{l}\text { Diastole before consuming } \\
\text { Habbatussauda }\end{array}$ & 0.972 & 20 & 0.793 \\
\hline $\begin{array}{l}\text { Systole after consuming } \\
\text { Habbatussauda }\end{array}$ & 0.958 & 20 & 0.505 \\
\hline $\begin{array}{l}\text { Diastole after consuming } \\
\text { Habbatussauda }\end{array}$ & 0.921 & 20 & 0.102 \\
\hline
\end{tabular}

According Table 4, results of normality test using the Shapiro-Wilk test showed that probability value $(P)$ of systole before $(0.096)$, diastole before is 0.793 , systole 
after is 0.505 , diastole after is 0.102 is more than 0.05 so it was concluded that the data are normally distributed.

Table 5. Test result Shapiro Wilk Glucose.

\begin{tabular}{lcccc}
\hline \multicolumn{4}{c}{ Shapiro-wilk } & \\
\hline & $\begin{array}{l}\text { Statistic } \\
\text { (mg/dL) }\end{array}$ & Df & $\boldsymbol{P}$ \\
\hline Before consuming Habbatussauda & 0.969 & 20 & 0.730 \\
After consuming Habbatussauda & 0.946 & 20 & 0.309 \\
\hline
\end{tabular}

According Table 5, results of normality the test results for glucose showed that probability value $(P)$ of before consuming Habbatussauda is 0.730 and after consuming Habbatussauda is 0.309 is more than 0.05 so it was concluded that the data are normally distributed.

According Table 6, normality test for uric acid showed that probability value before consumption Habbatussauda is 0.113 and probability value after consumption of Habbatussauda is 0.883 is more than 0.05 so it was concluded that the data are normally distributed.
Table 6. Test result Shapiro Wilk Uric Acid.

\begin{tabular}{cccc}
\hline \multicolumn{4}{c}{ Shapiro-Wilk } \\
& $\begin{array}{l}\text { Statistic } \\
\text { (mg/dL) }\end{array}$ & Df & $\boldsymbol{P}$ \\
\hline Before consuming Habbatussauda & 0.923 & 20 & 0.113 \\
\hline After consuming Habbatussauda & 0.977 & 20 & 0.883 \\
\hline
\end{tabular}

From the results above, it is known that the data are normally distributed with a probability value (sig.) more than $0.05(\mathrm{P}>0.05)$. Furthermore, the data will be tested average differences using the $t$ test with the following results.

Table 7 shows decreasing in the average systolic and diastolic blood pressure before and after consuming Habbatussauda, a decrease of $7.73 \mathrm{mmHg}$ in systolic and a decrease of $5.7 \mathrm{mmHg}$ in diastole with a probability value (sig.) For systole (0.019) and diastole (0.012) is less than 0.05 it can be seen that there are differences in blood pressure values were significantly before and after consuming Habbatussauda.

Table 7. T test Result Blood Pressure.

\begin{tabular}{|c|c|c|c|c|c|c|c|c|c|}
\hline \multirow{2}{*}{ No } & \multirow{2}{*}{ Variable } & \multicolumn{2}{|c|}{ Average } & \multicolumn{2}{|c|}{ Standard Deviaton } & \multicolumn{2}{|c|}{ T test } & \multicolumn{2}{|c|}{$\boldsymbol{P}$} \\
\hline & & Systole (mmHg) & Diastole (mmHg) & Systole & Diastole & Systole & Diastole & Systole & Diastole \\
\hline 1. & Before & 119.01 & 81.6 & 16.56852 & 9.13870 & \multirow{2}{*}{2.556} & \multirow{2}{*}{2.778} & \multirow{2}{*}{0.019} & \multirow{2}{*}{0.012} \\
\hline 2. & After & 11.37067 & 10.90099 & 75.9 & 111.35 & & & & \\
\hline
\end{tabular}

Table 8. T test Result Glucose.

\begin{tabular}{cccccc}
\hline No & Variable & Average $(\mathbf{m g} / \mathbf{d L})$ & Standard Deviation & T test & $\boldsymbol{P}$ \\
\hline 1. & Before & 5.065 & 1.26419 & \multirow{2}{*}{2.338} & 0.030 \\
\hline 2. & After & 4.555 & 0.96381 & & \\
\hline
\end{tabular}

Table 9. T test Result Uric Acid.

\begin{tabular}{cccccc}
\hline No & Variable & Average $(\mathbf{m g} / \mathbf{d L})$ & Standard Deviation & T test & $\boldsymbol{P}$ \\
\hline 1. & Before & 90.30 & 12.60368 & 2.181 & 0.042 \\
\hline 2. & After & 84.60 & 13.23631 & & \\
\hline
\end{tabular}

Table 8 shows decreasing the average content of glucose before and after consuming Habbatussauda, a decrease of $5.7 \mathrm{mg} / \mathrm{dL}$ with a probability value (sig.) 0.042 less than 0.05 so that it can be seen that there is a difference in the value of the content of glucose in the body significant before and after consuming Habbatussauda.
Table 9 shows decreasing the average content of uric acid before and after consuming Habbatussauda, a decrease of $0.51 \mathrm{mg} / \mathrm{dL}$ with a probability value (sig.) 0.030 less than 0.05 so it can be seen that there are differences in the content value of uric acid in the body significant before and after consuming Habbatussauda. 


\section{CONCLUSIONS}

This study shows the results of statistical analysis Habbatussauda's benefits on blood pressure, glucose and uric acid that showed significant differences between the values before and after consuming Habbatussauda. It is visible from a probability value obtained is less than 0.05 .

From these results and from previous studies show that Habbatussauda can lower blood pressure values, glucose and uric acid contained in the body, this research confirm previous studies that have examined the Habbatussauda's benefits both medically and other research.

\section{REFERENCES}

Abdulelah, H. A. A., \& Zainal-Abidin, B. A. H. (2007). In vivo anti-malarial tests of Nigella sativa (Black Seed) different extracts. Am J Pharmacol Toxicol, 2(2), 46-50.

Aboul-Enein, H. Y., \& Abou-Basha, L. I. (1995). Simple HPLC method for the determination of thymoquinone in black seed oil (Nigella sativa Linn). Journal of Liquid Chromatography \& Related Technologies, 18(5), 895-902.

Hussain, D. A., \& Hussain, M. M. (2016). Nigella sativa (black seed) is an effective herbal remedy for every disease except death-a Prophetic statement which modern scientists confirm unanimously: a review. Adv Med Plant Res, 4(2), 27-57.

Osman, M. T., Hamza, A. J. A., Omar, E., \& Adnan, A. (2014). The new miracle of Habbatus Sauda: its major component thymoquinone can be used in the management of autoimmune diseases. Procedia-Social and Behavioral Sciences, 121, 304314.

Salahshoor, M. R., Haghjoo, M., Roshankhah, S., Makalani, F., \& Jalili, C. (2018). Effect of thymoquinone on reproductive parameter in morphine-treated male mice. Advanced biomedical research, 7 .

Suhendi, A., \& Sutrisna, E. M. (2011). Antihyperurisemia activity of water extract of black seed (Coleus ambonicusLour) in balb-c mice and its standardization. Indonesian Journal of Pharmacy, 77-84.

World Health Organization. (2010). World health statistics 2010. World Health Organization. 